\title{
Development of Financial Reporting Principles
}

\author{
Kulikova L.I. \\ Gafieva G.M.
}

Kazan Federal University, Institute of Management, Economics and Finance, Kazan, 420008, Russia

\section{Doi:10.5901/mjss.2014.v5n24p38}

\section{Abstract}

The paper discusses the link between the principles of financial reporting and informational needs of users who provide limited resources to the entity. It is argued that development of economic environment has led to the shift in resources, that are limited, and consequently has changed the primary user of financial reporting. This change is to be reflected in financial reporting principles as its aim is satisfaction of users' informational needs.

Keywords: financial statement, international financial reporting standards, integrated reporting

\section{Introduction}

Today, Russian generally accepted accounting principles are under reformation in accordance with the International Financial Reporting Standards. At the same, time the International Financial Reporting Standards are also going through substantial review process. These standards were formed and developed in an era of industrial production. Since then the business environment, models and value creation process has changed significantly. A recent crisis has also raised new challenges in from of the accounting system and regulators. To face these challenges new laws, standards and requirements have been introduced. Furthermore, the increasing complexity of production processes and economic transactions has led to additional disclosure requirements. The volume of disclosed information in financial reporting increased, new report of sustainability has appeared. Despite the increase in the information supplied by accounting system, it is still claimed to be inadequate, fragmented and disconnected. Scandals involving transparency of financial reporting make it necessary to rethink the principles of financial reporting.

\section{Materials and Methods}

To do so we analyzed the development of financial principles and their perception trough available sources of information.

\section{Results and Discussion}

Multidirectional informational needs of financial reporting users cause a difficulty in unifying principles of financial reporting. For example, creditors want to know financial stability and realizable value of a company's assets. However, the owners of a company usually are interested in return on capital employed and in valuation of assets at cost. Based on the analysis of the historical development of financial reporting principles in Russia and abroad, we conclude that principles are based on informational needs of users who provide limited resources.

International Financial reporting standards initially aimed to satisfy informational needs of wide range of users. "Framework for preparation and presentation of financial statement" (IASB, 1989) stated that "The users of financial statement include present and potential investors, employees, lenders, suppliers and other trade creditors, customers, governments and their agencies and the public".

However, in 2004 International Accounting Standards Board started the joined review project of the framework with US Financial Accounting Standards Board (IASB, 2012). As a result of this project in 2010 revised chapter "Objectives and qualitative characteristics of financial reporting" was issued. In the new chapter the objective of financial reporting stated as "to provide financial information about reporting entity that is useful to existing and potential investors, lenders and other creditors in making decisions about providing recourses to the entity" (IASB,2010). This means, that it was 
recognized on the international level, that financial statement primary serves providers of capital. It should be noted that this approach came from US, where financial markets historically were more developed. Even so, that not for all countries' financial markets are the main capital provider, they have to accept this approach if they accept International Financial Reporting Standards.

Change in the primary users of the financial reporting triggered the change in financial reporting principles. First of all it changed the qualitative characteristics of financial statement.

Initially International Financial Reporting Standards followed four basic qualitative characteristics: understandability, relevance, comparability and reliability, - where reliability described through faithful representation, substance over form, neutrality, completeness and prudence. The last one - prudence - was eliminated from revised in 2010 Framework. It was argued that prudence principle conflicts with neutrality and may lead to understatement of income and overstatement of expenses (IASB, 2013). However, prudence principle was cornerstone of European and Russian accounting system. It defined measurement methods for assets and liabilities. All analysis and interpretations of financial reporting were based on assumption of prudence. Therefore, its elimination will change not only accounting treatment for elements of financial reporting, but the whole decision making process based on that information.

For a long time, the financial capital was the most critical recourse. However, current business conditions indicate the increasing role of human, social and natural capitals. This raises the need to reflect their contribution to the financial performance of the company. The absence of this information leads to bias and it does not allow making economic decisions based on comprehensive analysis. The International Financial Reporting Standards contain the tools to reflect, for example, environmental policy with the help of provisions. The contribution of each type of capital in the company's value and the financial results of its operations, both in the short and long term, also must be reflected in the report. Therefore, a mechanism should be found to assess human, social and natural capitals. As well as the format of financial reporting should be created, that allows disclosing this information.

The new integrated reporting format (IIRC, 2010) is intended to develop guidelines that address these challenges. An Integrated Report aims to display a company's stewardship not only of financial capital, but also of the other capitals, their interdependence and how they contribute to the value of the company. It also focuses on an ability to create and sustain value in the future, not on past financial performance and financial risk. Today's reporting is often said to be too compliance orientated, reducing the scope for organizations to exercise an appropriate amount of judgment. While a certain level of compliance orientation is necessary to ensure consistency and enable comparison, Integrated Reporting offers a principles-based approach that drives greater focus on factors that are material to particular sectors and organizations. It permits an organization to disclose its unique situation in clear and understandable language. However, the large number of estimates and forecasts leads to the subjectivity of accounting data and the complexity of their inspection. In our opinion, the reported data should be cleaned as much as possible from subjective estimation and allow its users to interpret it according to their interests.

\section{Conclusion}

It should be noted that in Russia, the scarcest resource continues to be the financial capital and the main purpose of the transition to international standards is access to international financial markets. The contribution of other types of capital in the creation and stability of the value of the company on a regular basis is not tracked. The new format of financial reporting will help Russian companies to realize importance of all types of capital employed and assess their contribution to the company's value. Considering sufficient amount of natural and human recourses in Russia, an integrated reporting model may increase investment appeal of the country.

Financial reporting is crucial element of business transactions. Making an investment decision always involves transaction cost. Globalization, complexity of business and financial structures constantly increase them. However, transparent financial reporting could sufficiently reduce them. At the same time disclosing all relevant information will allow companies to get fair market value of their shares. That will bring stability to financial markets, the importance of which was clearly showed in the last financial crises.

\section{References}

Ahern Jh, Kulikova I, Gafieva G., 2014. Falsification of financial results by American companies. International accounting. 16 (58-62).

IASB chairman defends stance on prudence http://www.corporategovernancereport.com/regulations/iasb-chairman-defends-stance-onprudence/\#more-153. (Accessed on 10 June 2014).

The International Accounting Standards Board, 1989. Framework for preparation and presentation of financial statement. 
The International Accounting Standards Board, 2010. Conceptual Framework.

The International Accounting Standards Board, 2012. IFRS Staff paper.

The International Accounting Standards Board, 2013. Discussion Paper: A Review of the Conceptual Framework for Financial Reporting. The International Integrated Reporting Committee, 2011. Towards integrated reporting. Communicating value in the 21st century. Discussion paper.

Owen, G. (2013). Integrated Reporting: A Review of Developments and their Implications for the Accounting Curriculum. Accounting Education, 22 (4), pp. 340-356.

Sneidere, R., Vigante, I. (2014). Legislative basis for corporate social responsibility reporting. Economic Annals-XXI, 3-4 (1), pp. 58-62.

Martins, A., Jorge, S., Sá, P. (2013). Price regulation and cost accounting: The case of the Portuguese seaport sector. International Journal of Law and Management, 55 (6), pp. 444-463.

Bohušová, H., Svoboda, P. (2013). The evaluation of new methodological approaches to lease reporting on the side of lessor. Acta Universitatis Agriculturae et Silviculturae Mendelianae Brunensis, 61 (4), pp. 881-891.

Hellmann, A., Perera, H., Patel, C. (2013). Continental European accounting model and accounting modernization in Germany. Advances in Accounting, 29 (1), pp. 124-133

Otrusinová, M., Hýblová, E. (2013). International harmonization of accounting demands a new approach to accounting education. Acta Universitatis Agriculturae et Silviculturae Mendelianae Brunensis, 61 (2), pp. 427-435 